\title{
Konstribusi self esteem terhadap perilaku bullying siswa
}

\author{
Fita Jufri $^{\left.{ }^{*}\right)}$, Yeni Karneli ${ }^{2}$ \\ ${ }^{12}$ Universitas Negeri Padang, Indonesia
}

\begin{tabular}{l} 
Article Info \\
\hline Article history: \\
Received Feb $23^{\text {th }}, 2021$ \\
Revised Feb $09^{\text {th }}, 2021$ \\
Accepted Mar $12^{\text {th }}, 2021$
\end{tabular}

\section{Keyword:}

Kontribusi

Self Esteem

Perilaku Bullying

\begin{abstract}
Penelitian ini bertujuan untuk menganalisis kontribusi self esteem terhadap perilaku bullying siswa. Sampel dalam penelitian ini adalah 67 siswa. Alat ukur yang digunakan adalah angket self esteem dan perilaku bullying, analisis data dilakukan dengan deskriptif korelasional pendekatan kuantitatif. Berdasarkan pengolahan data temuan dan pembahasan hasil penelitian, maka dapat dikemukakan kesimpulan bahwa gambaran perilaku bullying siswa berada pada kategori tinggi, self-esteem siswa berada pada kategori sedang. Berdasarkan analisis regresi self-esteem benar-benar dapat memprediksi peilaku bullying siswa. Semakin tinggi self-esteem maka semakin rendah pula perilaku bullying siswa. Sebaliknya, semakin rendah self-esteem maka semakin tinggi pula perilaku bullying siwa.
\end{abstract}

(C) 2021 The Authors. Published by IICET.

This is an open access article under the CC BY-NC-SA license

(https://creativecommons.org/licenses/by-nc-sa/4.0

\section{Corresponding Author:}

Fita Jufri

Universitas Negeri Padang

Email: fitajufri1231@gmail.com

\section{Pendahuluan}

Masa remaja merupakan masa transisi seseorang dari anak-anak menjadi dewasa, yang melibatkan perubahan biologis, kognitif, dan sosio-emosional (Santrock, 2003). Remaja cenderung mudah terpengaruh oleh kebiasaan sehari-hari dan mempengaruhi lingkungan sekitar tempat mereka bergaul (Durandt, Bidjuni, \& Ismanto, 2015; Widiastuti \& Margaretha, 2011; Agustiani, 2006). Bichler (Fatimah, 2010) menyebutkan ciriciri remaja usia 12-15 tahun adalah berperilaku kasar, cenderung berusaha berperilaku tidak toleran terhadap orang lain dan tidak berusaha mengendalikan diri dan perasaan. Kemampuan mengendalikan diri merupakan salah satu kunci untuk mengurangi terjadinya perilaku kekerasan karena dengan pengendalian diri individu dapat merasa tenang sehingga emosional dirinya tidak mudah marah dan pada akhirnya mampu membina hubungan baik dengan teman (Thaib, 2013; Brook, 2011).

Salah satu fenomena yang menyita perhatian di dunia pendidikan saat ini adalah perilaku bullying yang dilakukan oleh siswa. Bullying adalah sebuah situasi dimana terjadinya penyalahgunaan kekuatan atau kekuasaan yang dilakukan oleh seseorang atau sekelompok, kuat secara fisik dan kuat secara mental (Sejiwa, 2008; Echols \& Shadily, 2000; Egan \& Todorov, 2009; Wiyani, 2012; Coloroso, 2007). Perilaku bullying yang dilakukan oleh siswa di sekolah semakin banyak diberitakan di halaman media cetak maupun elektronik. Hal ini membuktikan bahwa nilai-nilai kemanusiaan pada remaja telah hilang (Wiyani, 2012). Berdasarkan data Komisi Perlindungan Anak Indonesia (KPAI), sejak tahun 2011 hingga 2016 ditemukan sekitar 253 kasus bullying yang terdiri dari 122 peserta didik yang menjadi korban dan 131 peserta didik menjadi pelaku. Jumlah korban bullying dari tahun ke tahun naik turun, tahun 2011 berjumlah 56 kasus, tahun 2012 berjumlah 130 kasus, tahun 2013 berjumlah 96 kasus, tahun 2014 berjumlah 159 kasus, tahun 2015 berjumlah 154 kasus dan tahun 2016 berjumlah 97 kasus. Data KPAI juga menggambarkan jumlah pelaku bullying yang cenderung 
meningkat dari tahun ke tahun, dari 48 kasus pada tahun 2011 menjadi 112 kasus pada tahun 2016 dan terus meningkat di tahun 2017.

Perilaku bullying dapat dipengaruhi oleh beberapa faktor. Faktor tersebut terdiri dari faktor internal (dari dalam) dan faktor eksternal (dari luar). Salah satu faktor eksternal (dari luar) yang mempengaruhi perilaku bullying yaitu teman sebaya dan media sosial. Teman sebaya dan media sosial sangat mempengaruhi munculnya perilaku bullying baik di lingkungan sekolah maupun di lingkungan masyarakat (Sullivan, 2000). Berdasarkan keterangan yang di peroleh dari guru BK Pondok Pesantren Modren SMP Prof. Dr. Buya Hamka perilaku bullying secara verbal dengan persentasi $60 \%$ untuk siswa boarding school dan $70 \%$ untuk siwa fullday scholl. Dengan jumlah siswa SMP Buya Hamka dengan total siswa 250 siswa perempuan dan laki-laki. Perilaku bullying akan memunculkan penilaian diri terhadap diri sendiri maupun orang lain. Self esteem merupakan sekumpulan sikap individu dalam memandang dirinya, dalam hal ini dapat bersifat positif dan dapat pula bersifat negatif (Stevanus 2003; Baron \& Byrne, 2003; Ghufron \& Risnawita, 2010; Brecht, 2000; Branden, 2005).

\section{Metode}

Penelitian ini menggunakan metode deskriptif korelasional dengan pendekatan kuantitatif. Adapun variabel dalam penelitian ini terdiri dari variabel self-esteem (X) serta perilaku bullying siswa (Y). Populasi dalam penelitian ini adalah siswa di SMP Pesantren Modern Terpadu (PMT) Prof. Dr. Hamka II Kota Padang yang terdaftar pada Tahun Ajaran 2020/2021 yang berjumlah 316 siswa. Penarikan sampel penelitian dilakukan dengan menggunakan teknik purposive sampling. Maka sampel yang termasuk dalam kriteria yang telah ditentukan dalam penelitian ini berjumlah 67 siswa yaitu siswa yang terindikasi pernah melakukan perilaku bullying baik secara verbal maupun non-verbal dan berdasarkan rekomendasi dari guru BK. Analisis data menggunakan metode deskriptif korelasi dengan analisis regresi sederhana dibantu dengan SPSS 20.

\section{Hasil dan Pembahasan}

Hasil pengumpulan dan pengolahan data melalui instrumen self esteem dari keseluruhan sampel berjumlah 67 siswa, dapat dilihat pada tabel.

Tabel 1. Distribusi Frekuensi dan Persentase Self Esteem

\begin{tabular}{|c|c|c|c|}
\hline Interval Skor & Kategori & Frekuensi & (\%) \\
\hline$\geq 30$ & Sangat Tinggi & 0 & 0,0 \\
\hline $27-29$ & Tinggi & 5 & 7,5 \\
\hline $20-26$ & Sedang & 32 & 47,8 \\
\hline $14-19$ & Rendah & 26 & 38,8 \\
\hline$\leq 13$ & Sangat Rendah & 4 & 6,0 \\
\hline \multicolumn{2}{|c|}{ Total } & 67 & 100 \\
\hline
\end{tabular}

Berdasarkan tabel 1, dapat diketahui bahwa secara umum siswa memiliki self esteem yang yang berada pada kategori sedang sebanyak 32 siswa dengan jumlah persentase mencapai 47,8\%. Pengumpulan data variabel perilaku bullying diperoleh dari responden penelitian sebanyak 67 orang siswa. Deskripsi hasil analisis yang telah dilakukan dapat dilihat pada tabel 3 .

Tabel 2. Distribusi Frekuensi dan Persentase Perilaku Bullying

\begin{tabular}{|c|c|c|c|}
\hline Interval Skor & Kategori & Frekuensi & $(\%)$ \\
\hline $169-200$ & Sangat Tinggi & 8 & 11,9 \\
\hline $136-168$ & Tinggi & 38 & 56,7 \\
\hline $103-135$ & Sedang & 16 & 23,9 \\
\hline $70-102$ & Rendah & 4 & 6,0 \\
\hline$\leq 69$ & Sangat Rendah & 1 & 1,5 \\
\hline \multicolumn{2}{|c|}{ Total } & 67 & 100 \\
\hline
\end{tabular}

Pada tabel 2 diketahui bahwa frekuensi perilaku bullying siswa di sekolah didominasi oleh sebagian besar siswa yang memiliki kategori perilaku bullying yang tinggi sebanyak 38 siswa, yaitu dengan jumlah persentase mencapai $56,7 \%$. 
Pedoman yang dipakai dalam uji normalitas menggunakan uji Kolmogorov-Smirnov yaitu membandingkan koefisien Asymp. Sig. atau P-value dengan taraf signifikansi 0,05. Maka didapatkan hasil pada tabel sebagai berikut.

Tebel 3. Hasil Uji Normalitas Data Self-Esteem (X) dan Perilaku Bullying (Y)

\begin{tabular}{cccc}
\hline Variabel & Asymp. Sig & Signifikan & Keterangan \\
\hline Self-Esteem $\left(\mathbf{X}_{\mathbf{1}}\right)$ & 0,573 & 0,05 & Normal \\
\hline Perilaku Bullying $(\mathbf{Y})$ & 0,705 & 0,05 & Normal \\
\hline
\end{tabular}

Pada tabel 3 menunjukan bahwa, kedua variabel yang memiliki skor Asymp. Sig. lebih besar dari taraf signifikansi yang telah ditetapkan $(0,05)$. Artinya, data dari kedua variabel tersebut berdistribusi normal. Uji linieritas dalam penelitian ini menggunakan persamaan garis regresi. Apabila $F_{\text {hitung }}>F_{\text {tabel }}$ pada taraf signifikansi $\alpha=0.05$. Hasil pengujian linearitas data dapat dilihat pada tabel berikut.

Tabel 4. Hasil Uji Linearitas Self-Esteem (X) dan Perilaku Bullying (Y)

\begin{tabular}{ccccc}
\hline Variabel & F & Linearity & Taraf & Kesimpulan \\
$\mathrm{X}-\mathrm{Y}$ & 36,302 & 0,000 & Signifikansi & Linier \\
\hline
\end{tabular}

Berdasarkan tabel 4, hasil uji linearitas memperlihatkan variabel self esteem (X) terhadap perilaku Bullying (Y) dengan nilai Linearity $0,000<$ taraf signifikansi 0,05 . Hasil ini memberikan arti bahwa data setiap variabel independent (bebas) linier terhadap variabel dependent (terikat). Berdasarkan hasil uji persyaratan analisis yang telah dilakukan, maka dapat disimpulkan bahwa data variabel penelitian ini memenuhi persyaratan untuk dilakukan pengujian hipotesis statistik dengan menggunakan regresi sederhana bullying berdasarkan nilai koefisien regresi yang diperoleh. Berikut dipaparkan hasil analisis pada pengujian hipotesis pertama penelitian ini.

Tabel 5. Hasil Regresi Sederhana Self-Esteem (X), Terhadap Perilaku Bullying (Y)

\begin{tabular}{ccc}
\hline Variabel & $\boldsymbol{R}$ & $\boldsymbol{R}$ Square \\
$\mathrm{X}-\mathrm{Y}$ &, $512^{\mathrm{a}}$ &, 262 \\
\hline
\end{tabular}

Sesuai dengan tampilan pada tabel 5 , terlihat bahwa nilai korelasi $(r)$ yang diperoleh adalah sebesar 0,512 , dengan nilai koefesiensi regresi ( $R$ Square) sebesar 0,262. Hasil ini memberikan makna bahwa self-esteem berkorelasi terhadap perilaku bullying siswa dimana nilai korelasinya berada pada kategori sedang yaitu dengan nilai $r$ yang diperoleh sebesar 0,512 dan besarnya kontribusi variabel self-esteem terhadap perilaku bullying siswa adalah sebesar $26,2 \%$. Sedangkan sisanya sebesar $73,8 \%$ dipengaruhi oleh faktor lainnya. Setelah diketahui koefisien regresi dan besarnya kontribusi self-esteem terhadap perilaku bullying, maka langkah selanjutnya dilakukan uji signifikansi terhadap model regresi yang bertujuan untuk menjelaskan apakah variansi nilai variabel self-esteem dapat menjelaskan variansi nilai variabel perilaku bullying dengan menggunakan besaran nilai F. Hasilnya dapat dilihat pada tabel 6.

Tabel 6. Hasil Uji Signifikansi Self-Esteem (X), Terhadap Perilaku Bullying (Y)

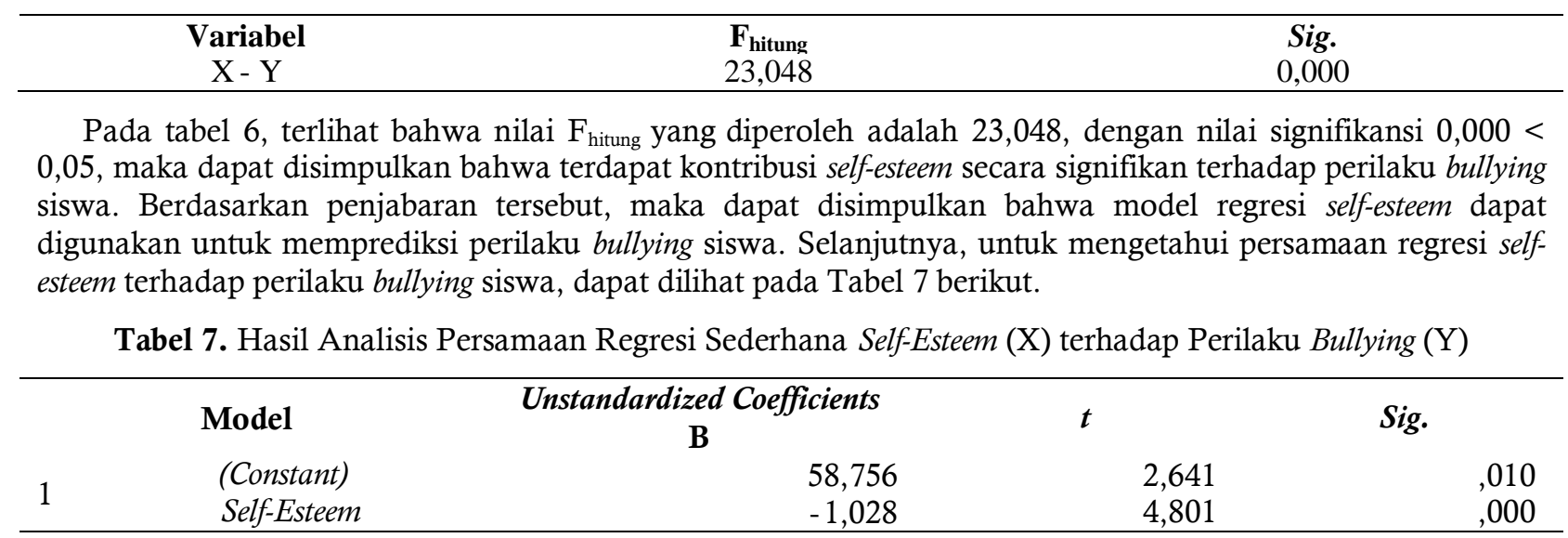


Hasil analisis yang ditampilkan pada Tabel 7, terlihat bahwa nilai konstanta yang diperoleh adalah sebesar 58,756 dengan nilai koefesien regresi sebesar - 1,028. Berdasarkan hasil tersebut, maka persamaan regresi selfesteem terhadap perilaku bullying dapat digambarkan sebagai berikut.

$$
\begin{gathered}
\widehat{Y}=a+b X \\
\widehat{Y}=58,756-1,028(X)
\end{gathered}
$$

Persamaan regresi self-esteem terhadap perilaku bullying memiliki makna bahwa Konstanta sebesar 58,756 menyatakan bahwa jika tidak ada self-esteem, maka skor perilaku bullying siswa adalah 58,756. Koefesiensi regresi (B) sebesar - 1,028 menyatakan bahwa setiap terjadi peningkatan skor self-esteem sebesar 1 , maka perilaku bullying siswa akan menurun sebesar - 1,028.

Setelah mendapatkan persamaan regresi, maka selanjutnya dilakukan uji signifikansi untuk mengetahui persamaan regresi self-esteem yang diperoleh benar-benar valid dalam memprediksi perilaku bullying. Berdasarkan Tabel 22, terlihat bahwa nilai signifikansinya 0,000 $<0,05$, maka dengan demikian dapat dimaknai bahwa persamaan regresi yang diperoleh adalah signifikan atau dengan kata lain, self-esteem benarbenar dapat memprediksi peilaku bullying siswa.

Self-esteem yang rendah telah terbukti berhubungan dengan banyak fenomena negatif, termasuk meningkatnya kehamilan remaja, penyalahgunaan narkoba, kekerasan, depresi, kecemasan sosial, dan bunuh diri (Refnadi, 2018). Faktor-faktor seperti jenis kelamin, ras, tingkat ekonomi, orientasi seksual, status imigran, dan lebih tampaknya dipengaruhi tingkat self-esteem (Guindon, 2009). Selain itu Dengan rendahnya self-esteem tentu hal ini akan menghambat siswa untuk berprestasi. Semakin tinggi self-esteem seseorang maka dapat membantu siswa tersebut untuk berprestasi dalam belajar, begitupun sebaliknya, semakin rendah self-esteem seseorang maka akan menghambat siswa untuk berprestasi (Adila, 2010; Irawati \& Hajat, 2012). Self-esteem merupakan salah satu faktor keberhasilan individu dalam kehidupannya, karena perkembangan self-esteem pada seorang remaja akan menentukan keberhasilan maupun kegagalan dimasa mendatang. Sebagai penilaian terhadap diri sendiri, maka pengembangan self-esteem menjadi bagian penting dalam pendidikan karena diharapkan mampu memproses penemuan konsep diri positif pada jiwa anak.

Jika self-esteem pada diri anak terpenuhi maka secara otyomatis anak akan terhindar dari perilaku negatif dan tindakan yang menyimpang lainnya salah satunya perilaku bullying. Hal ini sesuai dengan pendapat Maslow (Rohmah, 2012), harga diri sebagai suatu kebutuhan yang harus dipenuhi oleh manusia. Kebutuhan akan rasa harga diri ini oleh Maslow dibagi menjadi dua bagian yaitu : (1) Penghormatan atau penghargaan dari diri sendiri yang mencakup hasrat untuk memperoleh kompetensi, rasa percaya diri, kekuatan pribadi, adekuasi, kemandirian dan kebebasan. Individu ingin mengetahui atau yakin bahwa dirinya berharga serta mampu mengatasi segala tantangan dalan hidupnya. (2) Penghargaan dari orang lain, antara lain prestasi. Dalam hal ini individu butuh penghargaan atas apa-apa yang dilakukannya (Mendari, 2010).

Untuk meningkatkan self-esteem dapat dilakukakan dengan Salah satu pendekatan konseling yang dapat digunakan untuk membantu klien dalam permasalahan harga diri adalah Terapi Cognitive Behavior, yang dalam penelitian bidang bimbingan dan konseling ini disebut dengan Konseling Cognitive Behavior (Habsy, 2017). Selain itu program pengembangan keterampilan resiliensi dapat meningkatkan self-esteem pada remaja (Aunillah \& Adiyanti, 2015). Berdasarkan pengaruh Role Playing terhadap ketiga komponen yang ada dalam Self-esteem (General Self Esteem, Pesonal Self-Esteem, dan Social Self Esteem) membuktikan bahwa bimbingan kelompok dengan menggunakan teknik bermain peran bermanfaat sekali dalam upaya meningkatkan selfesteem siswa. Layanan bimbingan kelompok yang telah yang diamati dengan demikian anak-anak atau anggota kelompok akan merasakan langsung dampak dari apa yang telah mereka lakukan (Awlawi, 2013).

\section{Simpulan}

Berdasarkan temuan dan pembahasan hasil gambaran perilaku bullying siswa berada pada kategori tinggi, self-esteem dan kematangan emosional siswa kelas VII berada pada kategori sedang. Semakin tinggi selfesteem maka semakin rendah pula perilaku bullying siswa. Sebaliknya, semakin rendah self-esteem maka semakin tinggi pula perilaku bullying siwa.

\section{Referensi}

Adila, M. D. (2010). Hubungan self esteem dengan optimisme meraih kesuksesan karir pada mahasiswa Fakultas Psikologi UIN Syarif Hidayatullah Jakarta.

Agustiani, H. (2006). Agustiani, Hendriati.(2006). Psikologi Perkembangan "Pendekatan Ekologi kaitannya 
dengan Konsep Diri dan Penyesuaian Diri pada Remaja”. Bandung: PT Refika Aditama. Jurnal Psikologi Undip. Vol, 10(2).

Amnda, V., Wulandari, S., Wulandari, S., Nabila Syah, S., Andi Restari, Y., Atikah, S., ... Arifin, Z. (2020). Bentuk Dan Dampak Perilaku Bullying Terhadap Peserta Didik. Jurnal Kepemimpinan Dan Pengurusan Sekolah, 5(1), 19-32. https://doi.org/10.34125/kp.v5i1.454

Astuti, P. R. (2008). Meredam Bullying: 3 cara efektif menanggulangi kekerasan pada anak. Jakarta: Grasindo.

Aunillah, F., \& Adiyanti, M. G. (2015). Program pengembangan keterampilan resiliensi untuk meningkatkan self-esteem pada remaja. Gadjah Mada Journal of Professional Psychology (GamaJPP), 1(1), 48-63.

Aunillah, F., \& Adiyanti, M. G. (2015). Program pengembangan keterampilan resiliensi untuk meningkatkan self-esteem pada remaja. Gadjah Mada Journal of Professional Psychology (GamaJPP), 1(1), 48-63.

Awlawi, A. H. (2013). Teknik Bermain Peran pada Layanan Bimbingan Kelompok untuk Meningkatkan SelfEsteem. Konselor, 2(1).

Dalimunthe, R. Z., Marjohan, M., \& Syahniar, S. (2016). Kontribusi Pengasuhan Orangtua dan Self Esteem terhadap Perilaku Bullying. Konselor, 3(4), 158-167.

Durandt, J. M., Bidjuni, H., \& Ismanto, A. Y. (2015). Hubungan antara pola asuh orang tua dengan kebiasaan merokok anak usia remaja 12-17 tahun di desa Kilometer Tiga Kecamatan Amurang. Jurnal Keperawatan, 3(1).

Fatimah, E. (2010). Psikologi perkembangan: perkembangan peserta didik. Bandung: Pustaka Setia.

Feriyal, F. (2014). Perilaku Bullying Ditinjau Dari Regulasi Emosi Dan Self-Esteem Pada Siswa Kelas Xi Jurusan Otomotif Stm Yudya Karya Magelang.

Fithria, F., \& Aulia, R. (2016). Faktor-Faktor yang Berhubungan dengan Perilaku Bullying. Idea Nursing Journal, 7(3), 9-17.

Guindon, M. H. (2009). Self-esteem across the lifespan: Issues and interventions. Taylor \& Francis.

Guindon, M. H. (2009). Self-esteem across the lifespan: Issues and interventions. Taylor \& Francis.

Habsy, B. A. (2017). Model konseling kelompok cognitive behavior untuk meningkatkan self esteem siswa SMK. Perspektif Ilmu Pendidikan, 31(1), 21-35.

Irawati, N., \& Hajat, N. (2012). Hubungan antara harga diri (self esteem) dengan prestasi belajar pada siswa SMKN 48 di Jakarta Timur. Econosains Jurnal Online Ekonomi Dan Pendidikan, 10(2), 193-210.

Klass, W. H., \& Hodge, S. E. (1978). Self-esteem in open and traditional classrooms. Journal of Educational Psychology, 70(5), 701.

Leary, M. R. (1999). Making sense of self-esteem. Current Directions in Psychological Science, 8(1), 32-35.

Mendari, A. S. (2010). Aplikasi teori hierarki kebutuhan Maslow dalam meningkatkan motivasi belajar mahasiswa. Widya Warta: Jurnal Ilmiah Universitas Katolik Widya Mandala Madiun, 34(01), 82-91.

Menesini, E., \& Salmivalli, C. (2017). Bullying in schools: the state of knowledge and effective interventions. Psychology, Health \& Medicine, 22(sup1), 240-253.

Refnadi, R. (2018). Konsep self-esteem serta implikasinya pada siswa. Jurnal EDUCATIO: Jurnal Pendidikan Indonesia, 4(1), 16. https://doi.org/10.29210/120182133

Refnadi, R. (2018). Konsep self-esteem serta implikasinya pada siswa. Jurnal EDUCATIO: Jurnal Pendidikan Indonesia, 4(1), 16. https://doi.org/10.29210/120182133

Rohmah, F. A. (2012). Pengaruh pelatihan harga diri terhadap penyesuaian diri pada remaja. HUMANITAS (Jurnal Psikologi Indonesia), 1(1), 53-63.

Santrock, J. W. (2003). Adolescence perkembangan remaja (terjemahan). Jakarta: Erlangga.

Thaib, E. N. (2013). Hubungan Antara prestasi belajar dengan kecerdasan emosional. JURNAL ILMIAH DIDAKTIKA: Media Ilmiah Pendidikan Dan Pengajaran, 13(2).

Widiastuti, R., \& Margaretha, M. (2011). Socio entrepreneurship: tinjauan teori dan perannya bagi masyarakat. Jurnal Manajemen, 11(1), 1-8. 